Viet Nam National University Ho Chi Minh City, Viet Nam

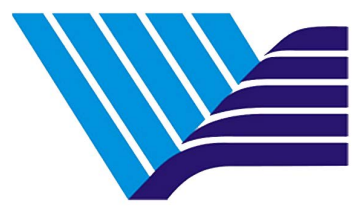

Science and Technology Development Journal

ISSN: 1859-0128

Volume 21: Issue 2 August 2018

Journal homepage: http://stdj.scienceandtechnology.com.vn

\title{
Research and design of an improved solar still for desalination
}

\author{
Thi Cam Trang Truong ${ }^{\star}$, Dinh Huy Pham, Phuoc Tri Phan \\ Faculty of Environmental Science, VNUHCM University of Science, Ho Chi Minh City, Viet Nam. \\ ttctrang@hcmus.edu.vn
}

ARTICLE DETAILS

\section{History}

Received: 09 April 2018

Accepted: 01 August 2018

Published: 31 August 2018

\section{Keywords}

Desalination, Solar still, Solar,

Solar vacuum tube

Check for updates

\begin{abstract}
Water is one of the most important resources on Earth because of its vital role for human beings and other living creatures. During the devastating drought in the Mekong Delta in 2016, millions of people had no access to the secure source of fresh water. This issue cautioned and influenced the Vietnamese government to find an effective desalination process for the coastal areas impacted heavily by salinization. However, desalination processes require large amounts of energy which can be a problem for the coastal areas due to the lack of energy and high cost. The main purpose of the study herein was to find an alternative solution for desalination by designing a desalination system using solar energy. The design was expected to provide a small size desalination system for households. The average output of the system was about $854 \mathrm{ml} /$ day with the productivity at $2223.54 \mathrm{ml} / \mathrm{day} / \mathrm{m}^{2}$. The average water capture efficiency was $80.5 \%$, the salt elimination efficiency of the system was about $99.99 \%$, and the salinity of the output water was below $2 \mathrm{ppm}$. The results are still far from ideal, but they indicate a potential solution for coping with the shortage of fresh water in coastal areas.
\end{abstract}

(C) 2018 Viet Nam National University Ho Chi Minh City, Viet Nam under a Creative Commons Attribution-NonCommercial-ShareAlike 4.0

\section{Introduction}

Water has been recognized as a basic human right. Large quantities of fresh water are required in many parts of the world for agricultural, industrial and domestic uses. Although 71 percent of the Earth's surface is covered with water, fresh water only accounts for $2.5 \%$ of the water while the remaining is saline water (according to USGS) Gleick (1996). With the increase of the human population over the first 20 years of the $21^{\text {st }}$ century (2000 - 2020) (about 50\% in Africa, 25\% in Asia, 14\% in the USA and, surprisingly,

${ }^{\star}$ Corresponding author's email address: ttctrang@ homus.edu.vn

Recommended citation: Truong, Thi Cam Trang, Pham, Dinh Huy and Phan, Phuoc Tri, (2018). Research and designof an improved solar still for desalination. Science and Technology Development Journal, 21 (2) 24-36. 
$2 \%$ negative, in Europe) Eltawil et al. (2009), about $40 \%$ of the world's population is struggling with serious water shortages, with the majority of this burden falling on people who live in rural areas Eltawil et al. (2009). In Vietnam, the drought which occurred in early 2016 caused massive damage for the Mekong Delta, which is considered to be the nation's granary. According to the government's statistics, salinization affected 13 provinces. The salinity of the water increased to $30 \mathrm{~g} / \mathrm{L}$. Living conditions for approximately 20 million people were heavily affected as about 160,000 hectares of rice paddies were damaged, equivalent to 800,000 tons of rice lost Website (c).

Most of the water available on earth has a salinity of up to $10,000 \mathrm{ppm}$ whereas the salinity of seawater is normally in the range of 35,000-45,000 ppm in the form of total dissolved salts. According to World Health Organization (WHO), the permissible limit of salinity in water is $500 \mathrm{ppm}$ and for special cases goes up to $1000 \mathrm{ppm}$ Eltawil et al. (2009). The annual water availability of $1000 \mathrm{~m}^{3}$ per capita constitutes the limit below which it will not be possible to guarantee an acceptable living standard as well as economic development Eltawil et al. (2009).

For the reasons mentioned above, it is urgent to find a desalination system or technology that is suitable for the situation. There are many available desalination technologies or systems, such as membrane technology (e.g. reverse osmosis (RO), electrodialysis, etc.), and heat technology (e.g. multi-stage-flash (MSF), solar still, etc.) Website (c). These technologies have different purposes and costs.

Since the main purpose of this research study was to find a possible alternative solution for salinity problems in remote areas where access to common energy resources is hardly available or still unavailable, we focused on the solar still (and trying to improve its productivity). The solar still is a suitable device for use in desalination at remote areas because of its simple design, easy operation and maintenance; it only requires heat from solar energy for operation Trieb et al. (2003). Beside these advantages, there are some drawbacks of this technology too. For example, the productivity of the device is impacted by weather factors, low efficiency, and requirement of a large area for installation. Across the world, there are many research studies in various countries using solar still to provide fresh water for rural areas; these countries include Turkey, India, the United States, etc. Rizzuti et al. (2007); Bhattacharyya (2013); V et al. (2012). Even in regions where other conservative energy exists (e.g. electricity and fossil fuel, that are widely available in the US), solar still is still an attractive choice as a means of conserving fossil fuel resources and limiting the carbon footprint of desalination V et al. (2012).

In terms of structure, there are many different types of solar devices that have been researched. For example, there is the single-slope double-basin solar still Al-Karaghouli and Alnaser (2004), single-slope triple-basin solar still El-Sebaii (2005), and pyramid-shaped solar still Fath et al. (2003). In terms of design, there also some unique solar still devices that have been conducted, such as the vertical solar still Boukar and Harmim (2005), which has a vertical single-wick (holding the feed water) and vertical condensing surface Boukar and Harmim (2005), and the solar still with multiple vertical wicks and a single vertical condensing surface with flat-plate reflector Tanaka and Nakatake (2005). In Vietnam, an eleventh grade student at Ben Tre province created a desalination device using the same principle as a solar still. The device is composed of many different materials, including a solar vacuum tube, insulation container, inox panel, and tube. The productivity of the device is 6 liters per day at a cost of 2 million Vietnamese dong Website (a). From the results of all the aforementioned studies, solar still for desalination is worth considering and improving as an option for providing fresh water to coastal area, especially with regards to the geography and tropical climate of Vietnam Website (b).

The aim of this study was to investigate and design an improved solar still device for desalination by adding more solar vacuum tubes and other materials to the conventional solar still to enhance the productivity of the device. 


\section{Materials-Methods}

\subsection{Materials}

\subsubsection{Equipment and chemicals}

The device consisted of two main parts: the body and the base. The body included the roof and the watercontaining tank made of $5 \mathrm{~mm}$ glass (can be purchased at glass store). The specifications of the solar vacuum tubes in this research study were: $1800 \mathrm{~mm}$ length, $58 \mathrm{~mm}$ outer tube diameter, $47 \mathrm{~mm}$ inner tube (made of $1.6 \mathrm{~mm}$ borosilicate 3.3 glass), and adsorption coating of $\mathrm{Al}-\mathrm{N} / \mathrm{Al}$ type (can be purchased at water heater or solar energy stores). The base was made of "V" shaped steel sized $38 \mathrm{~mm} \times 57 \mathrm{~mm} \times$ $3 \mathrm{~m}$ (can be purchase at a mechanical shop). The black pebbles scattered inside can be purchased at a construction materials store.

The meteorological devices used in this research to measure the environmental specifications included wind speed and direction, environment temperature, and solar radiation (device purchased from OGASAWARA KEIKI company, Japan).

Chemicals used in this research study were purchased from Merck Corporation (Germany). Saline water use in the experiments was diluted by salt $(\mathrm{NaCl}$; can be purchased at grocery store). The ionic chromatography machine used for analyzing the output water was purchased from Waters Corporation (USA).

\subsubsection{Device structure}

Water-containing tank and the roof top The water-containing tank was a trapezoidal prism made of 5 mm glass; this type of shape was chosen for the ability of installing 4 solar vacuum tubes. The detailed specifications of the water-containing tank were as follows: the bigger base was a square plane of $550 \mathrm{~mm}$ side length, the small base was a $270 \mathrm{~mm} \times 550 \mathrm{~mm}$ rectangular plane, the height of the trapezoidal base measured $300 \mathrm{~mm}$. There were four $630-\mathrm{mm}$ diameter holes on one lateral area for installing the solar vacuum tubes, with each hole $60 \mathrm{~mm}$ apart. There were also two $27 \mathrm{~mm}$ holes on another lateral area, one for input water and one for testing sample. In the bottom of the water-containing tank there was a $15-\mathrm{mm}$ layer of black pebbles for heat retention Figure 1.

The roof top was also made of $5 \mathrm{~mm}$ glass. On the inner edge of the roof top was a water trough system for collecting the water evaporation. The specifications of the roof top were as follows: total height of $15 \mathrm{~cm}$, and the base of $550 \mathrm{~mm}$ side length (square). The size of the water trough system was $550 \mathrm{~mm} \times 20 \mathrm{~mm} \times 20 \mathrm{~mm}$; on the outside of the trough system there was a $6-\mathrm{mm}$ diameter hole for removing the output water Figure 2.

The solar vacuum tubeis one of the most significantly improved part of the device. With 2 layers of glasses, separated by a layer of vacuum, the solar vacuum has the ability to increase the heat adsorption from solar radiation and decrease heat loss to the outside environment. The solar vacuum tubes, after attachment to the water-containing body of the device, were stabilized by a short 90-diameter pipe which was cut in the middle to hold the bottom of the solar glass tubes Figure 3.

\subsubsection{The base}

The main function of the base is to stabilize and to protect the equipment of the device against the effects of the environment. The "V" shaped steel was chosen as the base because of two main reasons: the total weight of the device was heavy (about 50-60 kg with full water) and "V" shaped steel is cheap and almost available from any mechanics store Figure 4.

The operating principle of the device 

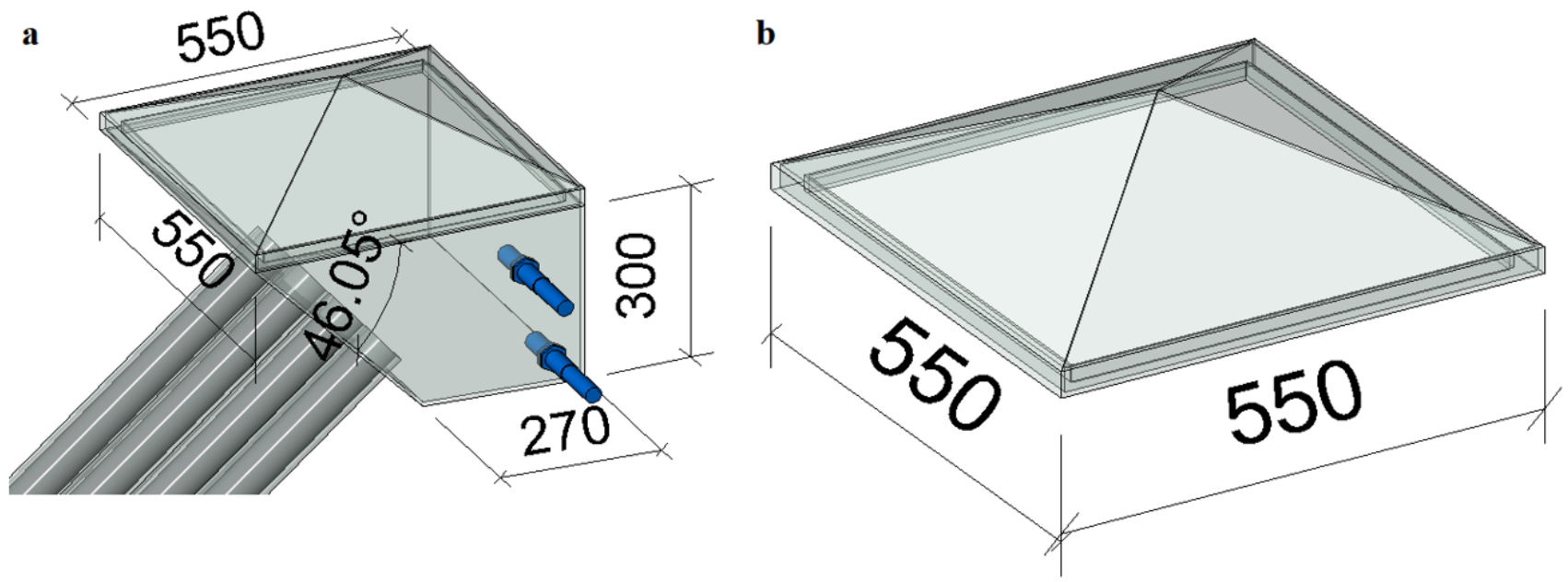

Figure 1. Drawing of the water-containing body in roof-top of the device with dimensions (a) and close-up (b).
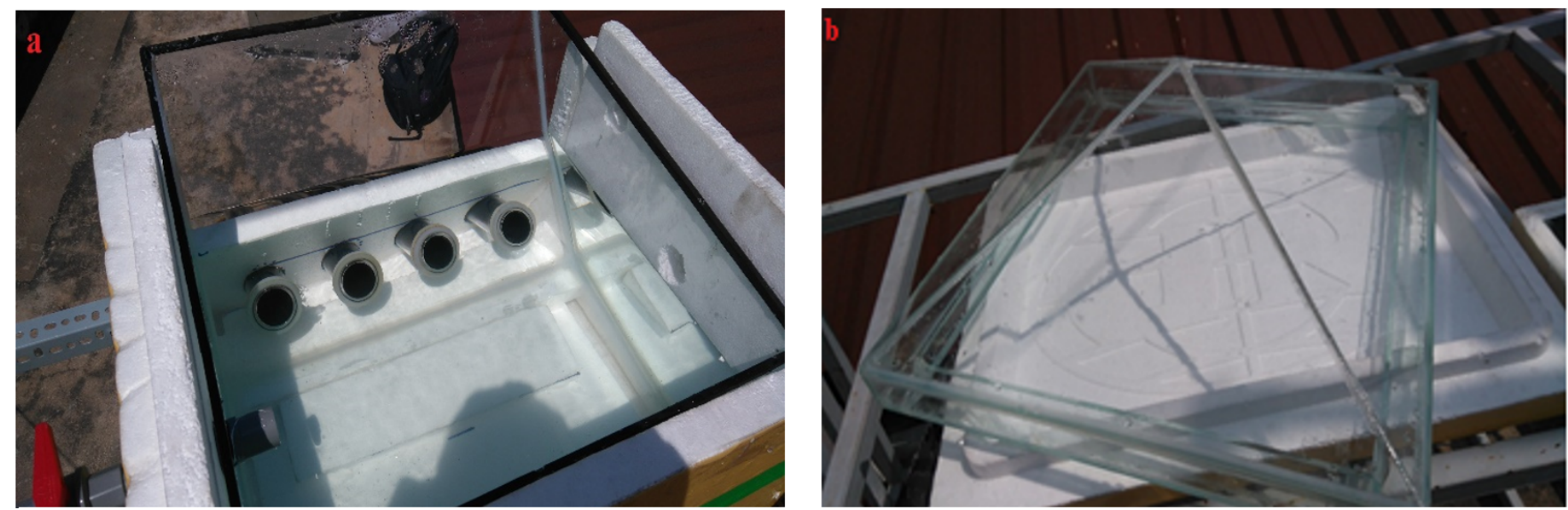

Figure 2. Inside of the water-containing body and roof-top (a) and inside of the water-containing body (b) the roof-top of the device.

The device operating principle is based on the principle of the cycle of water in nature. The evaporation rate of water in nature depends very much on temperature. These factors lead to the rationale for using a solar vacuum tube to increase the heat adsorption of solar radiation, thus leading to the rise of temperature of the water inside the device. Sunlight will pass through the outside layer of the solar vacuum tube and will be adsorbed by the second layer, which is coated by special adsorption coating, while the vacuum between the two layers keeps the heat from radiating back out to the environment. When the temperature goes up, the specific weight of water will become lighter and water will travel from the solar vacuum to the water-containing tank while the lower-temperature water from the tank will travel down the tube, creating an inner circulation of water Figure 5.

\subsection{Research method}

\subsubsection{Research content}

Available documents and studies on solar stills have referred to them as a simple testing model. We used them to in our investigations. After collecting enough data from the simple testing model, we began to 

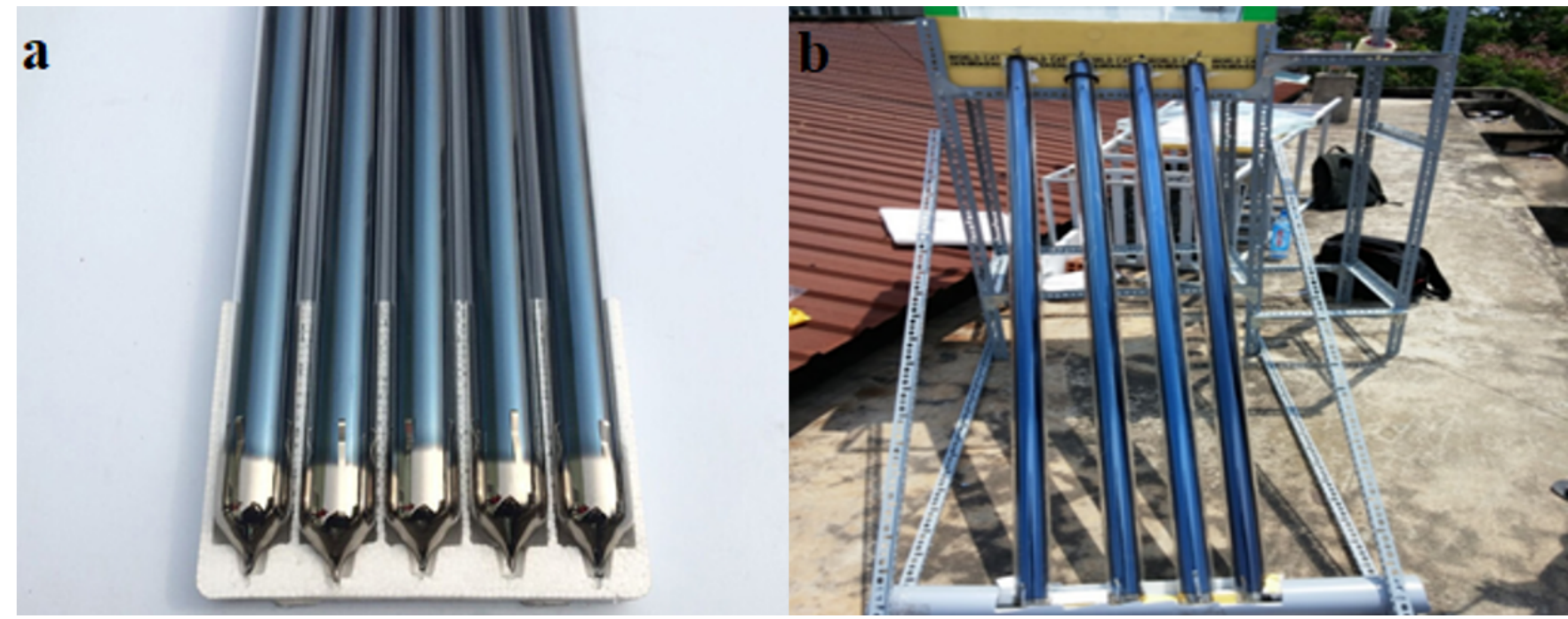

Figure 3. The solar glass tubes before attachment to the water-containing body of the device (a), and the solar glass tubes after attachment to the device with a short 90-diameter pipe for stabilization(b).

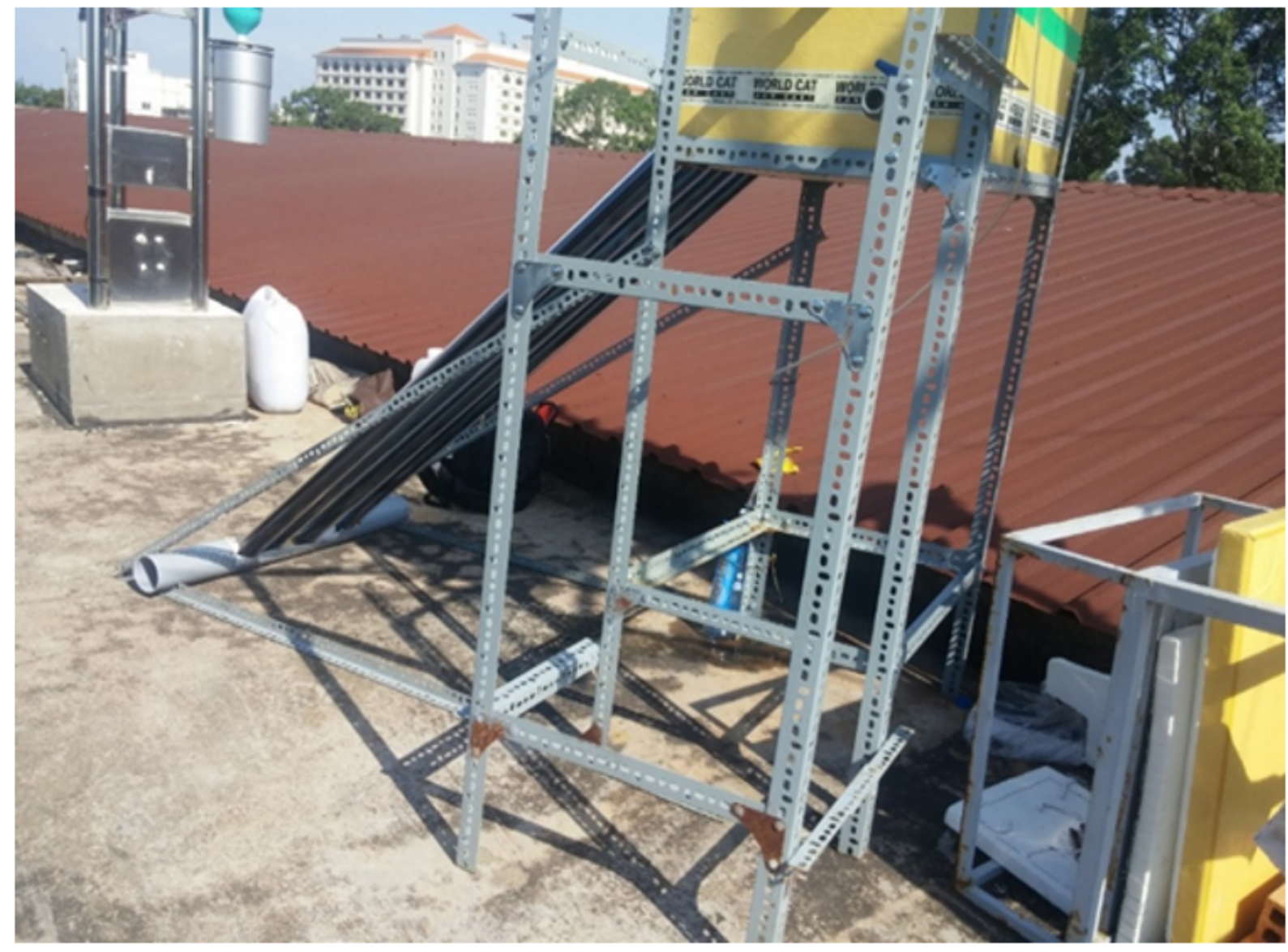

Figure 4. The base assembled from "V"shaped steel. 

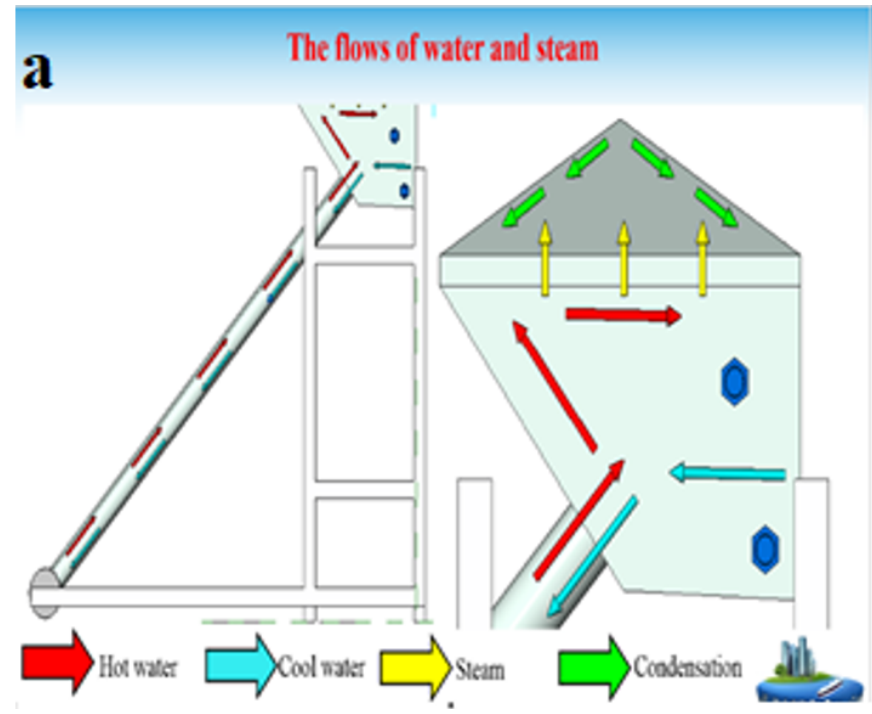
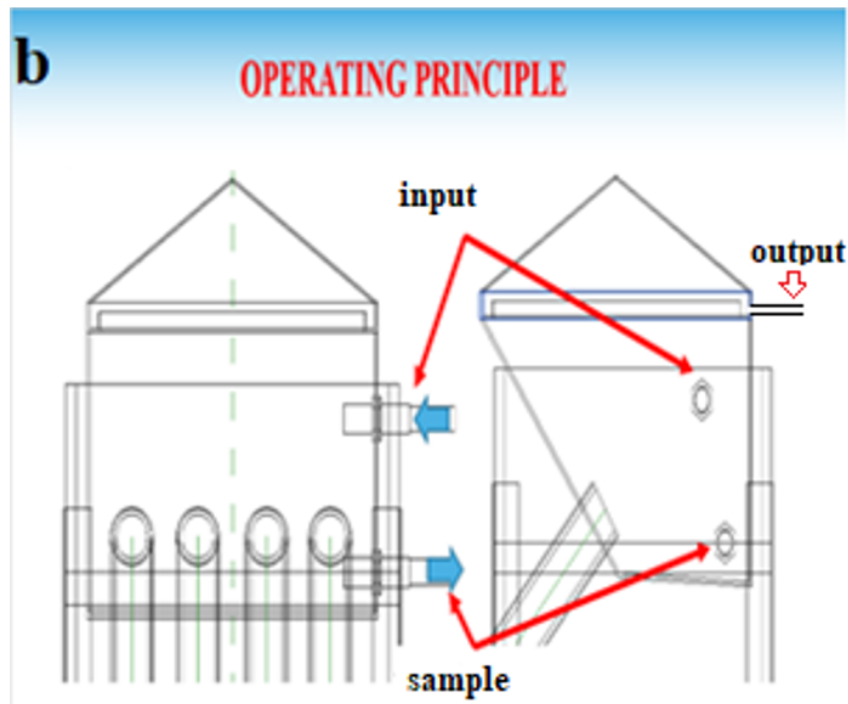

Figure 5. The working principle of the device. (a) Illustration of the water cycle inside the device, (b) The input, output and sample pipe of the device.

create the true-scale device. The completed device was placed on the roof top of block E of University of Science, Vietnam National University Ho Chi Minh City, for testing the productivity of the enhanced solar still under outside conditions. The device was examined during 24 hours of the day, from 08:30 to 08:30 next day. The time during daylight for evaluation was from 08:30 to 16:30. The parameters that were monitored were: temperature (inside and outside) of the device, the water level inside the water-containing tank, and the volume of the output water.

Environmental specifications that were monitored were wind speed and direction, environment temperature, and solar radiation; the measurements were collected by the Meteorological Station of the Environment Facility of the University of Science, Vietnam National University Ho Chi Minh City. If there was no nearby local meteorological station, we monitored the specific above environmental parameters using online websites or obtaining the information from the local Environmental Office.

\subsubsection{Sampling and analyzing method}

The input water was prepared in the laboratory by mixing distilled water with salt (the chloride concentration of the solution ranged from 22 to $29 \mathrm{~g} / \mathrm{L}$ ). The output water was sampled directly from the device and stored in the PET bottle at room condition. The chloride concentration of the input and water were analyzed by Mohr method and ion chromatography, respectively. Both input and output water were analyzed at the Chemical Analysis Department B16, University of Science.

\subsubsection{Productivity evaluation method}

The productivity of the device was evaluated by factors, including difference in temperature inside and outside the device, and change of weather factors (such as the intensity of sunlight, wind speed, rain, thunderstorm, etc.). 


\subsubsection{Statistical analysis method}

For continuous variable data, the mean and standard error of the mean were computed and when appropriate, comparisons between two groups of information were made to obtain a better understanding of the results.

The evaluation period was from the $15^{\text {th }}$ of April to $26^{\text {th }}$ of May, 2018. The most complete data from the 15-day evaluation period were chosen for the report. The study was conducted only once.

\section{Results}

\subsection{The volume of the output water}

As can be seen from Table 1 and Figure 6, the average volume of output water in daylight time (from 08:30 to 16:30) was approximately $343 \mathrm{ml}$ (which accounts for $40 \%$ of total output water in 24 hours). Meanwhile, the average output volume from the rest of the day (from 16:30 to 08:30 next day) was 515 $\mathrm{ml}$ (which accounts for $60 \%$ of total output water). However, in terms of performance, daylight hours provided better productivity at about $0.112 \mathrm{l} / \mathrm{m}^{2} / \mathrm{h}$, while productivity at night was just about $0.0841 / \mathrm{m}^{2} / \mathrm{h}$.

Table 1. The distribution ofwater in one day

\begin{tabular}{lllllllllll} 
Time Date & & \multicolumn{1}{c}{ Volume of output water (ml) } \\
& $\mathbf{8 : 3 0}$ & $\mathbf{9 : 3 0}$ & $\mathbf{1 0 : 3 0}$ & $\mathbf{1 1 : 3 0}$ & $\mathbf{1 2 : 3 0}$ & $\mathbf{1 3 : 3 0}$ & $\mathbf{1 4 : 3 0}$ & $\mathbf{1 5 : 3 0}$ & $\mathbf{1 6 : 3 0}$ & $\mathbf{8 : 3 0}$ (next day) \\
\hline 26-Apr & 0 & 0 & 0 & 0 & 0 & 10 & 112 & 156 & 211 & 715 \\
27-Apr & 0 & 0 & 0 & 20 & 70 & 170 & 238 & 350 & 467 & 1007 \\
28-Apr & 0 & 15 & 15 & 47 & 103 & 213 & 338 & 508 & 618 & 1438 \\
3-May & 0 & 0 & 30 & 60 & 82 & 110 & 160 & 230 & 286 & 776 \\
4-May & 0 & 0 & 0 & 50 & 90 & 190 & 256 & 340 & 470 & 1070 \\
5-May & 0 & 0 & 0 & 20 & 20 & 1120 & 175 & 265 & 331 & 801 \\
6-May & 0 & 0 & 20 & 40 & 80 & 180 & 250 & 300 & 300 & 775 \\
8-May & 0 & 0 & 0 & 30 & 50 & 165 & 259 & 409 & 513 & 1129 \\
9-May & 0 & 0 & 0 & 0 & 59 & 149 & & & & 639 \\
10-May & 0 & 0 & 0 & 46 & 85 & 171 & 225 & 300 & 384 & 784 \\
11-May & 0 & 0 & 0 & 0 & 76 & 134 & 198 & 275 & 370 & 905 \\
19-May & 0 & 0 & 0 & 40 & 86 & 150 & 212 & & & 672 \\
20-May & 0 & 0 & 0 & 49 & 80 & 149 & 206 & 269 & 325 & 765 \\
22-May & 0 & 0 & 0 & 0 & 62 & 125 & 125 & 164 & 203 & 733 \\
24-May & 0 & 0 & 0 & 35 & 35 & 155 & 210 & 250 & 312 & 660 \\
\hline
\end{tabular}

\subsection{The effect of temperature on the device}

As demonstrated in Figure 7, the temperature inside the device increased gradually during daylight time, reaching its peak during 13:30 to $16: 30$ o'clock. The highest temperature recorded was $70^{\circ} \mathrm{C}$ at $16: 30$ on April $28^{t h}$. It can also be seen that the cyclic temperature variation increased from 8:30 to 14:30, and began to decrease later.

From Figure 8, when the temperature of the device reached its highest point $\left(70^{\circ} \mathrm{C}\right)$ on the $28^{\text {th }}$ of April, the volume of output water also reached its highest point during that day (1438 ml). Similarly on the $4^{\text {th }}, 8^{\text {th }}$ and $11^{\text {th }}$ days of May, the output water volumes were higher compared to other days. 


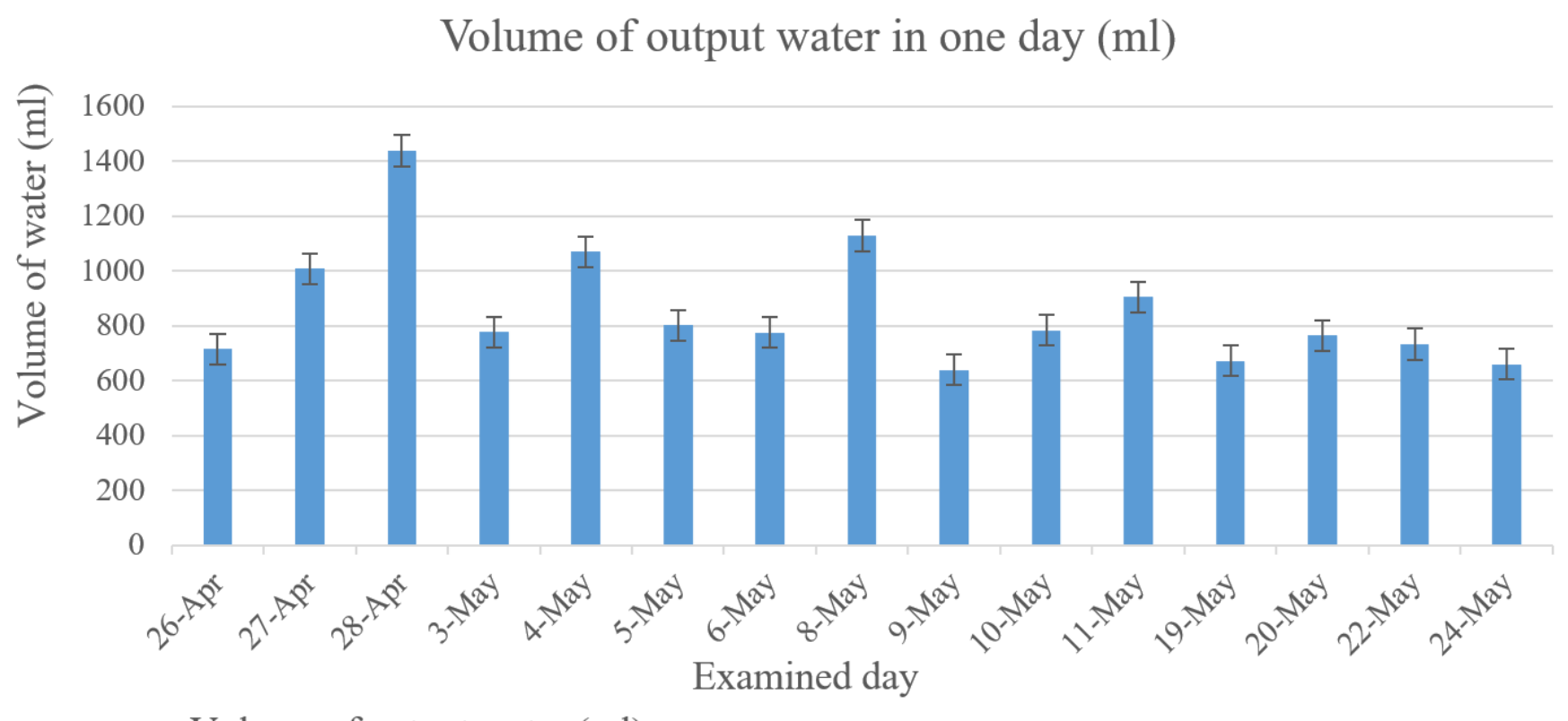

Volume of output water $(\mathrm{ml})$

Figure 6. Volume of output water in one day $(\mathbf{m l})$. The volume ofthe output water varied from the $26^{\text {th }}$ of April to $24^{\text {th }}$ of May due to the various changes in the environment. The highest volume recorded was on the $28^{\text {th }}$ of April -at $1438 \mathrm{ml}$.

\section{Average temperature inside and outside of the device $\left({ }^{\circ} \mathrm{C}\right)$}

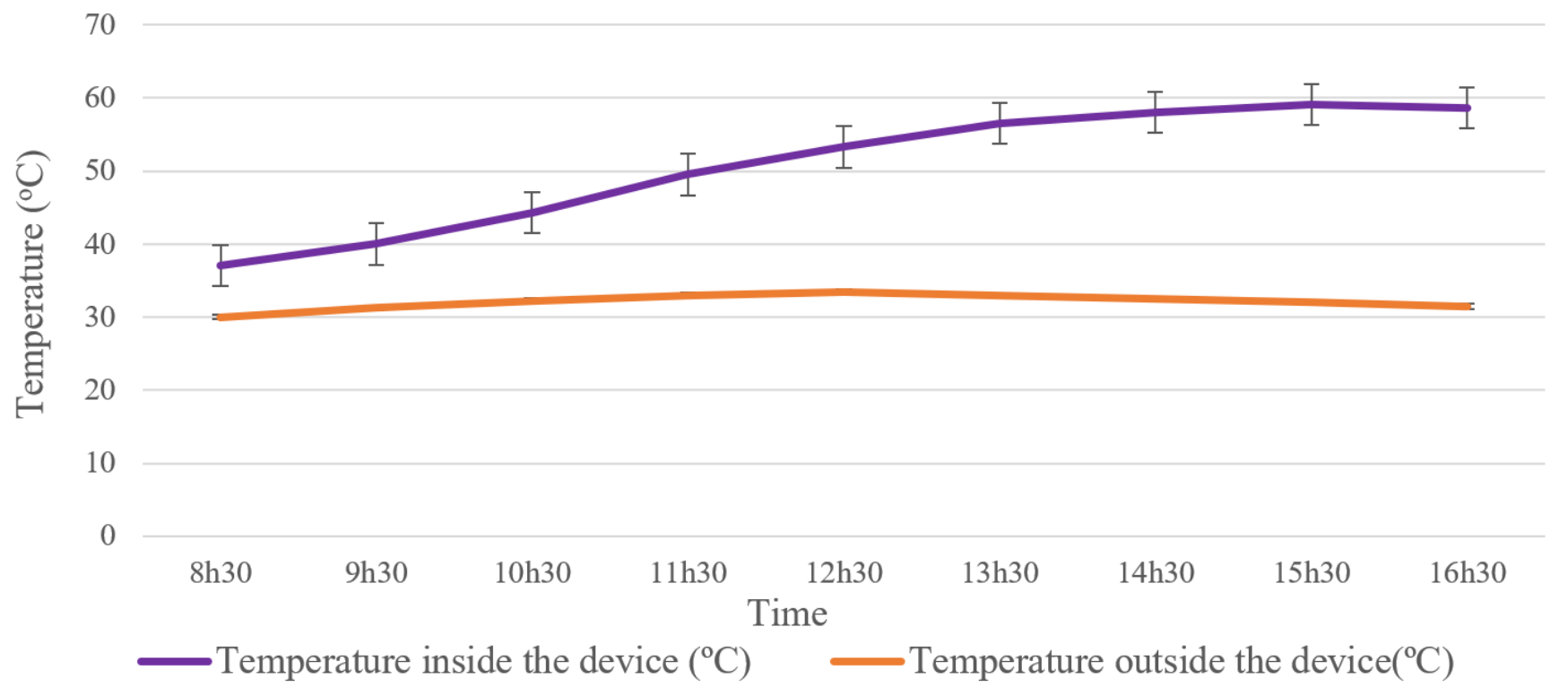

Figure 7. Average temperature of the inside and outside of the device. While the temperature inside the device increased gradually until $15 \mathrm{~h} 30$ and then started to decrease, the temperature outside the device increased slowly and reached its peak around $12 \mathrm{~h} 30$ and started to decrease. 


\section{Volume of output water and highest temperature}

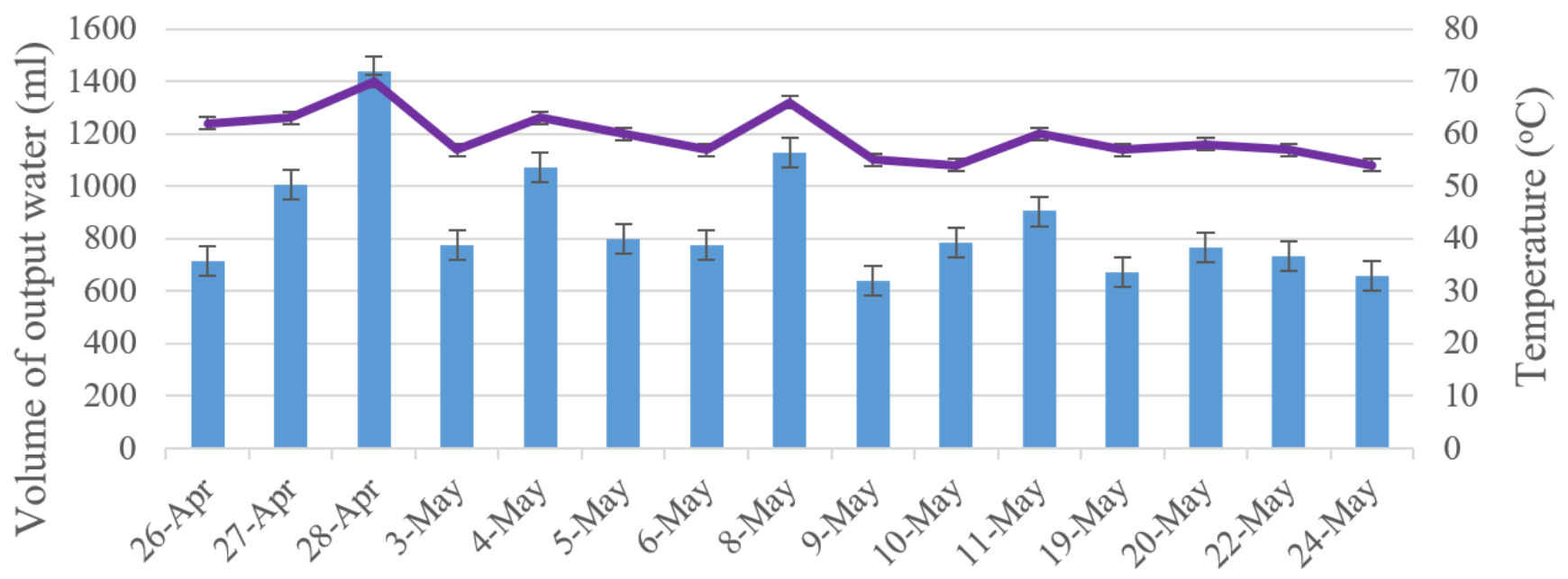

Examined day

Volume of output water $(\mathrm{ml}) \quad$ Highest temperature of the day $(\mathrm{oC})$

Figure 8. Volume of water and highest temperature during the examined period. The volume of output water reached its peak which correlated to the peaks of highest temperature recorded for that day.

\subsection{The effect of solar intensity on the device}

The results showed that the majority of solar radiation intensity changed in cycles, increasing from 8:30 to 13:30 o'clock and gradually decreasing at 16:30. From Figure 9, the highest solar intensity recorded was on the $28^{\text {th }}$ of April (average intensity was $668.96 \mathrm{~W} / \mathrm{m}^{2} / \mathrm{h}$ ). The days when the volume of output water was higher than other days were the $4^{\text {th }}, 8^{\text {th }}$, and $11^{\text {th }}$ of May; the peaks of solar intensity were similar to the highest temperature peaks recorded on those days.

\subsection{The effect of wind speed on the device}

As illustrated in Figure 10, from the $26^{\text {th }}$ of April to $8^{\text {th }}$ of May, the chart shows the volume of output water and wind speed had the same trend, such as reaching their peaks on April $28^{\text {th }}$, reaching the bottom on May $3^{r d}$, and reaching a small peak on May $4^{t h}$. However, on May $9^{\text {th }}$, due to the effects of rain and thunderstorm the amount of solar radiation decreased, leading to a decrease in the output water volume of the device, despite the increase in wind speed. Similarly on the $11^{t h}, 19^{t h}, 20^{t h}$ and $22^{\text {nd }}$ of May (particularly $22^{\text {nd }}$ of May), the average wind speed reached its highest during the examined period- at 27.7 $\mathrm{km} / \mathrm{h}$, due to a storm in the evaluated area.

\subsection{Desalination efficiency of the device}

From Table 2, the chloride concentration after the treatment is lower than the chloride concentration specified by the Vietnam National technical regulation on drinking water quality (QCVN 01:2009 - BYT; $\mathrm{Cl}^{-}$concentration range from 250 to $300 \mathrm{mg} / \mathrm{L}$ ) (Vietnam Ministry of Health). 


\section{Volume of output water and solar intensity}

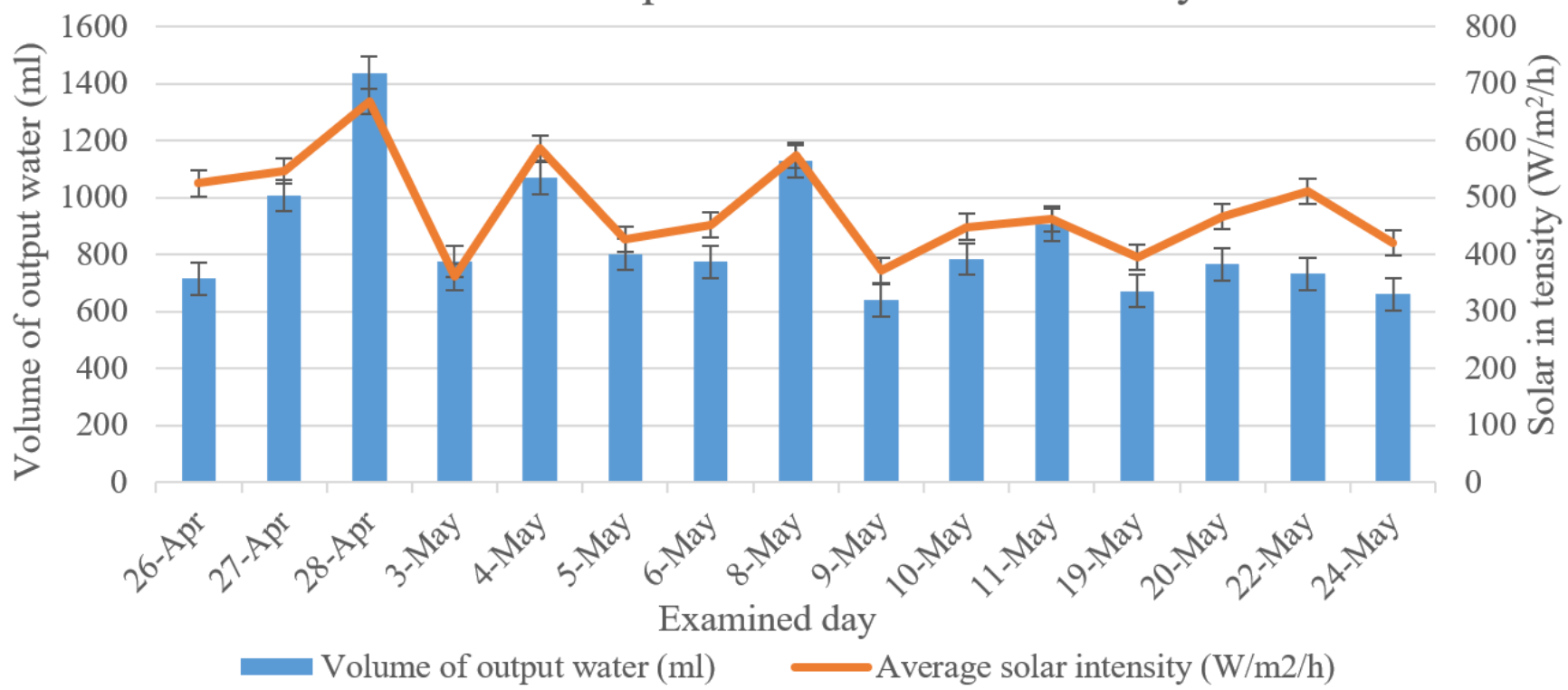

Figure 9. The volume of output water and solar intensity on the examined days. The average solar intensity peaks and bottoms corresponded with peaks and bottoms for output water volume.

Table 2. Chloride concentration of input and output water and the desalination efficiency of the device

\begin{tabular}{|c|c|c|c|}
\hline \multirow[t]{2}{*}{ Day } & \multicolumn{2}{|c|}{$\begin{array}{c}\text { Chloride } \\
\text { concentration (ppm) }\end{array}$} & \multirow{2}{*}{$\begin{array}{c}\text { Efficiency } \\
(\%)\end{array}$} \\
\hline & Input & Output & \\
\hline 26-Apr & 27340 & 1,6 & 99,99 \\
\hline 27-Apr & 29110 & 1,63 & 99,99 \\
\hline 28-Apr & 24850 & 1,45 & 99,99 \\
\hline 3-May & 23430 & 1,42 & 99,99 \\
\hline 4-May & 26270 & 1,51 & 99,99 \\
\hline 5-May & 25200 & 1,5 & 99,99 \\
\hline 6-May & 25920 & 1,47 & 99,99 \\
\hline 8-May & 26270 & 1,44 & 99,99 \\
\hline 9-May & 25020 & 1.45 & 99,99 \\
\hline 10-May & 24850 & 1.48 & 99,99 \\
\hline 11-May & 25560 & 1.51 & 99,99 \\
\hline 19-May & 22720 & 1.44 & 99,99 \\
\hline 20-May & 23080 & 1.45 & 99,99 \\
\hline 22-May & 22010 & 1.40 & 99,99 \\
\hline 24-May & 24140 & 1.42 & 99,99 \\
\hline Standard deviation & 1819.71 & 0 & 0 \\
\hline $\begin{array}{l}\text { Chloride concentrat } \\
\text { BYT(ppm): } 200-300\end{array}$ & $\begin{array}{l}\text { ation in } \\
O(* *)(15)\end{array}$ & $Q C V N \quad 0$ & :2009 \\
\hline
\end{tabular}




\section{Volume of output water and wind speed}

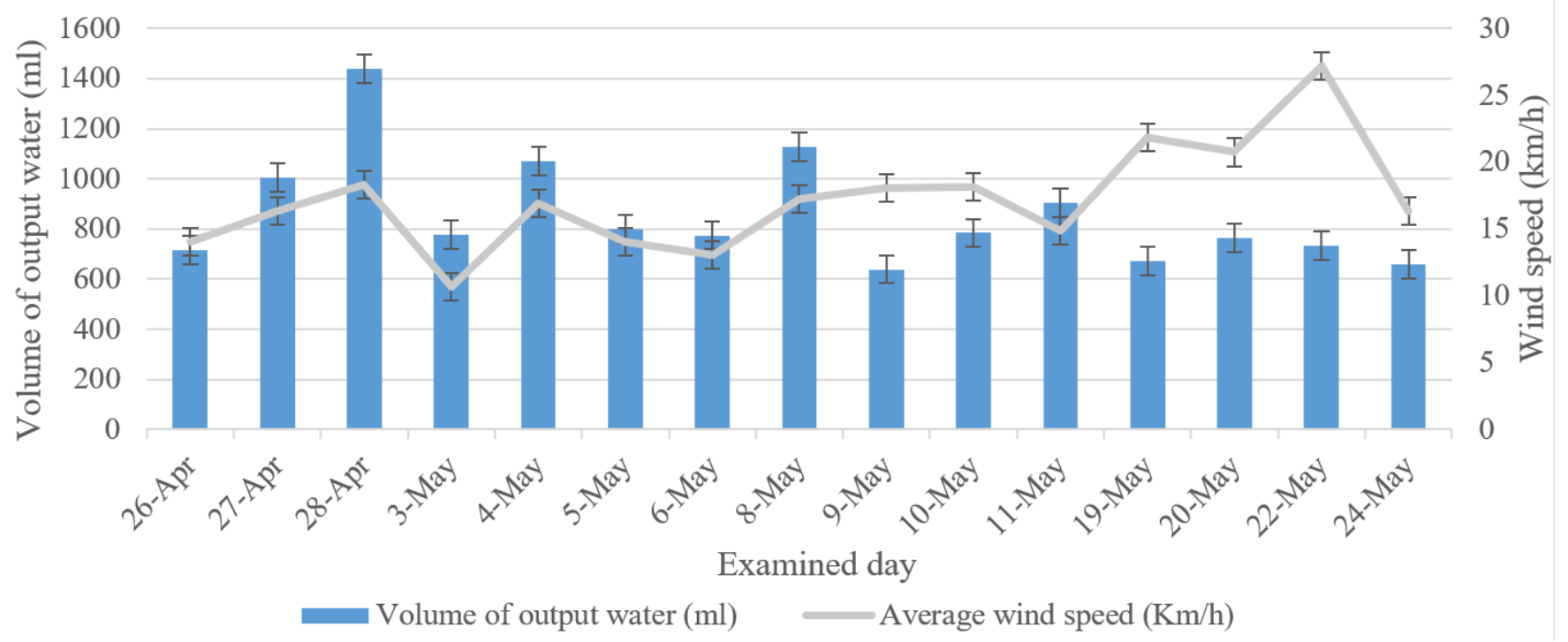

Figure 10. Volume of water and highest temperature on the examined days. Under normal weather conditions, the volume of output water and average wind speed show similarity (in increases and decreases). When there is extreme weather (such as storm or thunderstorm), the average wind speed changes dramatically while the output water decreases gradually.

\subsection{Productivity of the device}

The highest productivity of the device recorded was $3744.79 \mathrm{ml} / \mathrm{day} / \mathrm{m}^{2}$ (on April $28^{\text {th }}$ ) and the lowest was $1664.06 \mathrm{ml} / \mathrm{day} / \mathrm{m}^{2}$ (May $9^{\text {th }}$ ), while the average productivity of the device during the examined periods was $2234.2 \mathrm{ml} / \mathrm{day} / \mathrm{m}^{2}$. The change in the productivity of the device was non-cyclical, and depends on environment factors, such as solar intensity, wind speed, and outside temperature.

\section{Discussion}

Despite all the results collected during the examined period, the device still needs some more improvements before it can be applied in real-life situations. However, the research study shows a positive effect of using solar energy for desalination, especially with respect to the high efficiency in eliminating chloride from the water.

In terms of productivity, the average productivity of the device was $2234.2 \mathrm{ml} / \mathrm{day} / \mathrm{m}^{2}$, with the highest productivity recorded as $3744.79 \mathrm{ml} / \mathrm{day} / \mathrm{m}^{2}$ in April. Compared with the single-sloped solar stills in the report by H. E. S. Fath et.al (2003), whereby the maximum and minimum productivity were $4.251 / \mathrm{day}^{2} \mathrm{~m}^{2}$ in July and $0.65 \mathrm{l} / \mathrm{day} / \mathrm{m}^{2}$ in January and around $2.6 \mathrm{l} / \mathrm{day} / \mathrm{m}^{2}$ annual average daily Fath et al. (2003), the productivity of our device was relatively lower. Even though there was an improvement of the solar glass tubes, the design of the water-containing body was too big and required a large amount of input water to fill the solar glass tubes. The large volume of water can cause a disadvantage because more energy is required to heat up the water to fasten the evaporation progress.

In terms of price, the cost of making the device is about 1.8-2 million Dong, with is nearly the same as the price of the desalination device developed by the student from the Ben Tre province Website (a). However, our device has a much lower productivity (0.854 1/day compared with nearly $61 /$ day). The 
Table 3. Productivity of the device

\begin{tabular}{lcc} 
Date & Volume of output water $(\mathbf{m l})$ & Productivity of the device (ml/day/m2) \\
\hline 26-Apr & 715 & 1861.98 \\
27-Apr & 1007 & 2622.4 \\
28-Apr & 1438 & 3744.79 \\
3-May & 776 & 2020.83 \\
4-May & 1070 & 2786.46 \\
5-May & 801 & 2085.94 \\
6-May & 775 & 2018.23 \\
8-May & 1129 & 2940.1 \\
9-May & 639 & 1664.06 \\
10-May & 784 & 2041.67 \\
11-May & 905 & 2356.77 \\
19-May & 672 & 1750 \\
20-May & 765 & 1992.19 \\
22-May & 733 & 1908.85 \\
24-May & 660 & 1718.75 \\
Standard deviation & 218.4387677 & 568.8507518 \\
The average productivity of the & 2234.2 \\
device (ml/day/m2) & \\
Absorbent areas of the device $: 0.384 m 2$ & \\
\hline
\end{tabular}

lower productivity resulted from a mistake in the design of the water-containing body, make the price of the device become higher and the productivity of the device become lower. On the other hand, the desalination device of the student mentioned above makes use of cheap material, but with much better insulation equipment and design, their device productivity was much better than that of ours.

For future studies, we recommend reducing the water-containing size to decrease the cost of investment and to increase the temperature of the water inside for increasing the evaporation rate. Furthermore, a different shape of device is also recommended for the maximizing the solar radiation received and for better fixation of the solar glass tubes.

\section{Conclusion}

A complete desalination device, capable of desalinating in different weather conditions, was designed. Experimental results show that the average productivity of the device was $2234.2 \mathrm{ml} / \mathrm{day} / \mathrm{m}^{2}$. The chloride concentration quality of the output water passed the Vietnam National technical regulation test for drinking water (QCVN 01:2009 - BYT).

\section{Competing interests}

The authors declare that they have no conflicts of interest. 


\section{References}

Vietnam Ministry of Health (2009). QCVN 01:2009/BYT: National technical regulation on drinking water quality.

Al-Karaghouli, A. A. and Alnaser, W. E. (2004). Performances of single and double basin solar-stills. Applied Energy, 78(3):347-354.

Bhattacharyya, A. (2013). Solar Stills for Desalination of Water in Rural Households. International Journal of Environment and Sustainability (2013), vol 2 No. 1, pp. 21-30., 2(1):21-30.

Boukar, M. and Harmim, A. (2005). Performance evaluation of a one-sided vertical solar still tested in the desert of Algeria. Desalination, 183(1-3):113-126.

El-Sebaii, A. A. (2005). Thermal performance of a triple-basin solar still. Desalination, 174(1):23-37.

Eltawil, M. A., Zhengming, Z., and Yuan, L. (2009). A review of renewable energy technologies integrated with desalination systems. Renewable and Sustainable Energy Reviews, 13(9):2245-2262.

Fath, H. E., El-Samanoudy, M., Fahmy, K., and Hassabou, A. (2003). Thermal-economic analysis and comparison between pyramid-shaped and single-slope solar still configurations. Desalination, 159(1):69-79.

Gleick, P. H. (1996). Water resources. Encyclopedia of climate, weather, pages 817-823.

Rizzuti, L., Ettouney, H. M., and Cipollina, A. (2007). Solar desalination for the 21st century: a review of modern technologies and researches on desalination coupled to renewable energies. Springer Science \& Business Media.

Tanaka, H. and Nakatake, Y. (2005). Factors influencing the productivity of a multiple-effect diffusiontype solar still coupled with a flat plate reflector. Desalination, 186(1-3):299-310.

Trieb, F., Nitsch, J., Kronshage, S., Schillings, C., Brischke, L.-A., Knies, G., and Czisch, G. (2003). Combined solar power and desalination plants for the Mediterranean region-sustainable energy supply using large-scale solar thermal power plants. Desalination, 153(1-3):39-46.

V, J. H. L., Antar, M. A., Bilton, A., Blanco, J., and Zaragoza, G. (2012). Solar Desalination. In Annual review of heat transfer, volume 15, pages 277-347.

Website. http://khoahoc.tv/hoc-sinh-lop-11-va-thiet-bi-bien-nuoc-man-thanh-ngot-70827.

Website. https://en.wikipedia.org/wiki/Geography_of_Vietnam.

Website. https://vi.wikipedia.org/wiki/H\%E1\%BA\%A1n_h\%C3\%A1n_mi\%E1\%BB\%81n_Nam_Vi\%E1\% BB\%87t_Nam_2016 